\title{
ШЛЯХИ ОПТИМІЗАЦІЇ ВОДОСПОЖИВАННЯ СОНЯШНИКА ВИСОКООЛЕЇНОВОГО ТИПУ ЗА УМОВ ЗМІНИ КЛІМАТУ
}

\author{
ДОМАРАЦЬКИЙ Є.О. - доктор сільськогосподарських наук \\ https://orcid.org/0000-0003-3912-1611 \\ Херсонський державний аграрно-економічний університет \\ дОБРОВОЛЬСькИй А.В. - кандидат сільськогосподарських наук, \\ провідний науковий співробітник \\ https://orcid.org/0000-0003-1605-2879 \\ Державна установа «Миколаївська державна сільськогосподарська дослідна станція \\ Інституту зрошуваного землеробства Національної академії аграрних наук України» \\ козЛОВА О.П. - кандидат сільськогосподарських наук
} https://orcid.org/0000-0002-9062-5981

Херсонський державний аграрно-економічний університет

дОБРОВОЛЬСьКИй П.А. - здобувач вищої освіти ступеня доктора фрілософії, в.о. директора ДУ https://orcid.org/0000-0003-1605-2879

Державна установа «Миколаївська державна сільськогосподарська дослідна станція Інституту зрошуваного землеробства Національної академії аграрних наук України» ЛАВРИШИНА О.Є. - науковий співробітник https://orcid.org/0000-0002-2774-8866

Державна установа «Миколаївська державна сільськогосподарська дослідна станція Інституту зрошуваного землеробства Національної академії аграрних наук України»

Постановка проблеми. У гостро посушливих умовах Південного Степу України волога залишається вирішальним, а відтак і лімітуючим продуктивність чинником більшості сільськогосподарських культур. Від рівня її наявності у ґрунті та повітрі залежить особливість умов функціонування усіх без винятку агроценозів [1, с. 56; 2, с. 5-10]. Проте встановлено певну частину випадків формування високого рівня продуктивності того чи того агроценозу за умов істотного десіциту вологозабезпечення, відповідно, рослини мають механізми по-різному використовувати ґрунтові запаси вологи. Така здатність рослинних організмів не компенсує усього дефіциту, але частку його можна легко покрити економним використанням води [3, с. 4-20]. Активація процесів економного використання вологи рослинами сільськогосподарських культур за умов сучасних змін клімату як на глобальному, так і регіональному рівнях $€$ першочерговим завданням сталого розвитку галузі рослинництва.

Аналіз останніх досліджень і публікацій. Впродовж останніх років клімат планети зазнає істотних змін: одні країни потерпають від прояву аномально високих температур, інші, навпаки, від занадто суворих і снігових зим, що $є$ нехарактерними для тих чи інших місць. Екологи наголошують на глобальних змінах кліматичних умов, що проявляється у підвищенні середньої річної температури навколишнього середовища. Як наслідок такого процесу відбувається танення льодовиків і підвищення рівня Світового океану. За результатами кліматичних трансформацій відбувається і розбалансування усіх природних систем, що призводить до зміни режиму випадання опадів, температурних аномалій і збільшення частоти екстремальних явищ (урагани, градобої, повені, посухи, ерозія ґрунтів тощо) [4, с. 339; 5, с. 101-103].
Висновки багатьох учених свідчать про те, що кліматичні зміни, які частішають, можуть у майбутньому призвести до ще більш непередбачуваних наслідків, якщо людство не буде вживати відповідних попереджувальних заходів. Серед основних причин глобальної зміни клімату вчені світу відзначають: антропогенний фактор, підвищення в кругообігу вуглекислого газу, радіаційний прогрів атмосфери через поглинання інфрачервоного випромінювання за домінуючого впливу конвективного теплообміну, зміну течій в Північному Льодовитому океані (холодна Лабрадорська течія в районі Гренландії і теплий Гольфстрім), що призводить до періодичних катастрофічних епох стабільного зниження і збільшення температурного режиму в Північній півкулі. Клімат на регіональному рівні формується під впливом трьох найважливіших чинників: циркуляції атмосфери, сонячної інсоляції і рельєфу [6, с. 62]. За розробленими сценаріями очікуваних змін клімату до 2030 р. для різних районів нашої планети прогнозовано збільшення теплого періоду на 16-23 доби, а сума ефективних температур (більше $5{ }^{\circ} \mathrm{C}$ ) - на $437-481{ }^{\circ} \mathrm{C}$. [7, с. 9].

Наслідки зміни клімату для сільського господарства країни загалом досить складні та неоднозначні. Зміна клімату може мати і деякі позитивні аспекти, з істотною ймовірністю встановлено, що потепління до $2-2,5{ }^{\circ} \mathrm{C}$ може сприяти збільшенню урожайності багатьох сільськогосподарських культур (зокрема пшениці) на нашій території за деяких регіональних відмінностей. За межами цього потепління врожайність усіх культур буде зменшуватися. Нині підвищення температури в Україні вже становить $1-1,5{ }^{\circ} \mathrm{C}$ і наближається до $2{ }^{\circ} \mathrm{C}$. Вже майже немає територій із обмеженими тепловими ресурсами для вирощування теплолюбних культур (кукурудзи, сої) [8, с. 143-144; 9, с. 69-72]. 
Більшість рослин виробляють власні регулятори росту (цитокініни, гіббереліни, ауксини тощо). Однак в умовах прояву стресових ситуацій, що несуть зміни клімату (посуха, спека, вітер, нічні заморозки, фітотоксичність), вироблення власних фрітогормонів істотно знижується. Наслідком цього $є$ помітне ослаблення рослин, порушення внутрішньої програми їх розвитку та зниження імунітету, що робить рослини більш чутливими до впливу хвороб, шкідників та інших несприятливих фракторів довкілля. Для зменшення негативного впливу стресових фракторів та стабілізації процесів життєдіяльності рослинного організму можуть використовуватися препарати, що містять фітогормони та інші синтетичні стимулятори ростових процесів. Дія таких речовин спрямована на пролонгацію періоду активного протікання процесів фотосинтезу, призупинення життєдіяльності листового апарату, а відтак і посилення ростових функцій [10, с. 205; 11 , с. $10 ; 12$, с. 34$]$

Впродовж останніх 15 років були створені принципово нові високоефективні регулятори росту рослин, спроможні істотно підвищувати продуктивність сільськогосподарських культур. Згідно з розрахунками, витрати на застосування найкращих сучасних регуляторів росту на посівах зернових культур окуповуються вартістю приростів урожаю в 30-50 разів. Застосування регуляторів росту сьогодні $є$ одним із найбільш високорентабельних заходів підвищення врожайності всіх без винятку сільгоспкультур [13, с. 75].

Із досліджень науковців [14, с. $58-73 ; 15$, с. $62-63]$ встановлено, що соняшник $є$ вибагливою до забезпечення вологою культурою, однак потреба в ній за періодами його розвитку різна. До початку фази утворення суцвіть рослини соняшника витрачають близько $20 \%$ загальної кількості води, переважно із шару 0-50 см. Критичними для рослин соняшнику вважаються фази утворення кошика та цвітіння, у ці періоди споживається до 60\% запасів доступної вологи. Завдяки своїм біологічним особливостям він здатний використовувати вологу з глибини до 3 метрів, при цьому повністю зневоднюючи 1,5-метровий шар ґрунту.

Мета статті полягає у встановленні впливу сучасних комбінованих препаратів на оптимізацію водоспоживання агроценозів соняшника в незрошуваних умовах Південного Степу України за глобальних і регіональних змін клімату.

Постановка завдання. Дослідження проводили на дослідному полі Миколаївської дСДС IЗ3 НААН у незрошуваних умовах впродовж 2019-2021 рр. Ґрунт дослідних ділянок - чорнозем південний малогумусний пилувато-важкосуглинковий на карбонатному лесі. Глибина гумусового шару $30 \mathrm{~cm}$, перехідного - $60 \mathrm{~cm}$. Реакція ґрунтового розчину близька до нейтральної (pH 6,5-6,8), гідролітична кислотність в межах 2,00-2,52 мг екв. на 100 г ґрунту. Сума увібраних основ становить 32-35 мг екв. на 100 г ґрунту, ступінь насичення основами - 95,7 \%. Наявність гумусу в орному шарі ґрунту 2,90\%. За вмістом рухомих елементів ґрунт дослідної ділянки характеризується середнім вмістом нітратного азоту (30,0 мг/кг за Кравковим), середнім - рухомого фросфрору (100 мг/кг за Чіріковим) і дуже високим обмінного калію (300,0 мг/кг за Чіріковим).

Для досягнення поставленої мети програмою наукових досліджень передбачалося закладення двофакторного польового досліду, в якому вивчалися різні гібриди соняшнику високоолеїнового типу вітчизняної та зарубіжної селекції (фактор А), а також позакореневі обробки рослин багатофункціональними росторегулюючими препаратами з фунгіцидними властивостями (фрактор В). Гібриди соняшника, що вивчалися, - це Гектор і Оплот (оригінатор - Інститут рослинництва ім. В.Я. Юр'єва); ДСЛ403 та П64ГЕ133 (виробник Corteva, Brevant) та 8X477КЛ (виробник Dow Seeds). У досліді застосовували багатофункціональні росторегулюючі препарати хімічного походження Архітект ${ }^{\mathrm{TM}}$ та біологічного Хелафріт Комбі, вносили їх у вигляді позакореневих обробок гібридів соняшника у фразу 6-8 справжніх листків нормою 1 л/га. Багатофункціональність досліджуваних препаратів полягає у тому, що, окрім ростостимулюючих властивостей вони також володіють і фунгіцидним ефектом. Обробіток проводили ранцевим обприскувачем до 11 години дня в безвітряну погоду. На контрольному варіанті внесення препаратів не проводилося, обробіток рослин здійснювався чистою водою.

Повторність - триразова, посівна площа ділянки

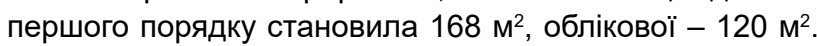
Польовий дослід розташований по попереднику пшениця озима. Сівбу проводили сівалкою УПС-8 нормою 48,7 тис. шт./га. Всі обліки і спостереження виконували відповідно до загальноприйнятих методик із проведення польових дослідів у рослинництві і сортовипробуванні, методичних рекомендацій Інституту рослинництва ім. В.Я. Юр'єва НААН, існуючих ДСТУ. Вологість ґрунту визначали термостатно-ваговим методом під час сівби та збирання культури.

Облік урожаю насіння проводили вручну, з подальшим перерахунком врожайності в тони на гектар за стандартної вологості та на 100\% чистоти. Оцінювання показників якості насіння проводили у лабораторії фрірми «Агро плюс».

Результати досліджень і обговорення. Відповідно до численних досліджень вітчизняних учених рівень реалізації біологічного потенціалу соняшнику за вирощування в незрошуваних умовах південного регіону не перевищує і $50 \%$ [16, с. 187]. Проте практичний досвід передових господарств України, які застосовують сучасні засоби інтенсифікації технологічних схем вирощування культури, дають змогу істотно покращити реалізацію генетичного потенціалу. I одним із вирішальних фракторів покращення життя рослин соняшника $є$ використання сучасних речовин комбінованої дії, що, окрім стимулюючого ефекту, мають і фунгіцидну складову частину, яка також покращує стійкість рослин до патогенної мікрофлори.

Аналіз погодних умов 2019-2021 років досліджень дає змогу класифікувати їх як середньопосушливі типові для цієї зони вирощування. Основні погодні умови років досліджень порівняно із середньобагаторічними даними наведено на рис. $1,2$. 


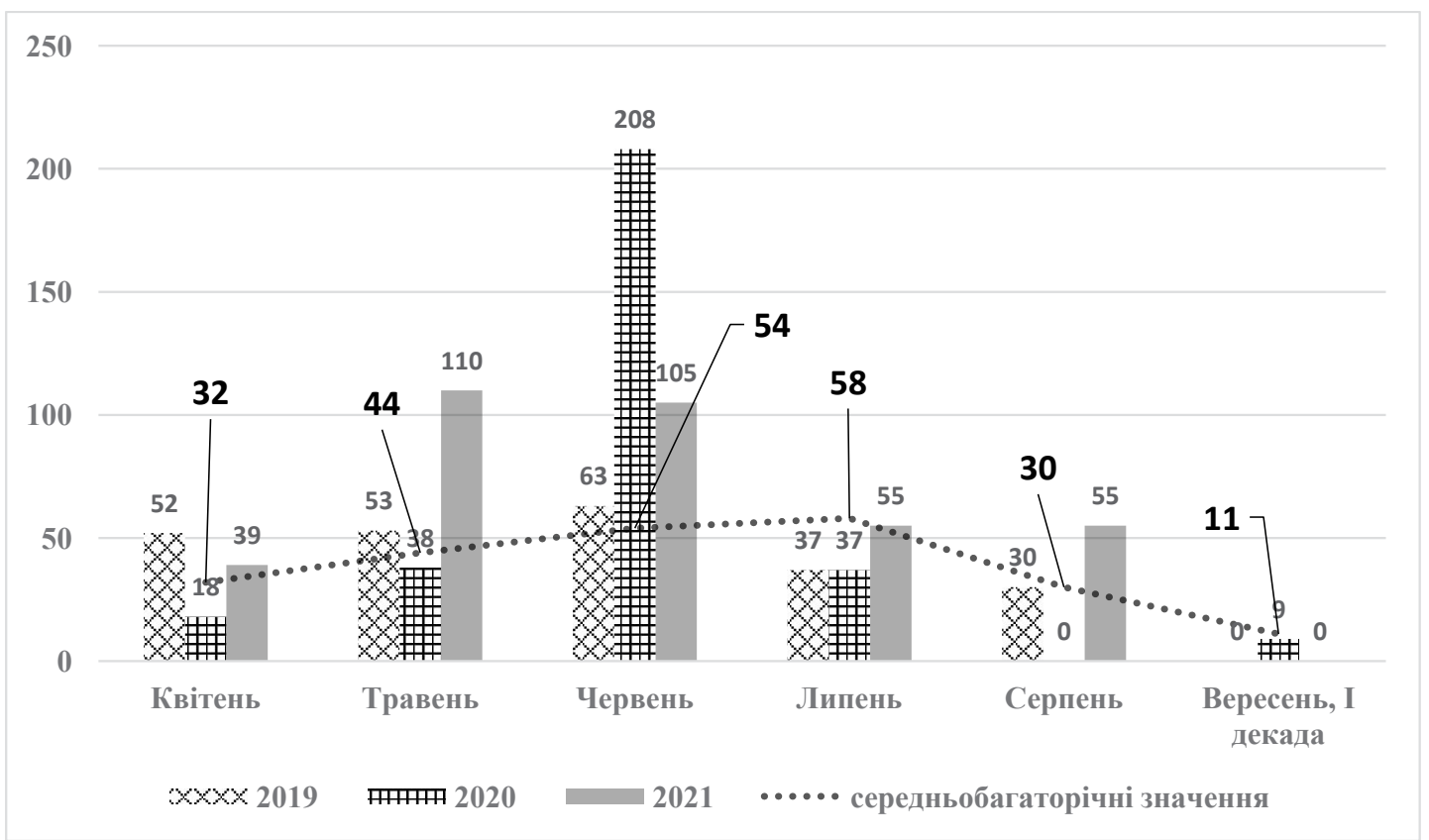

Рис. 1. Кількість опадів за вегетаційний період вирощування соняшнику, 2019-2021 pp., мм

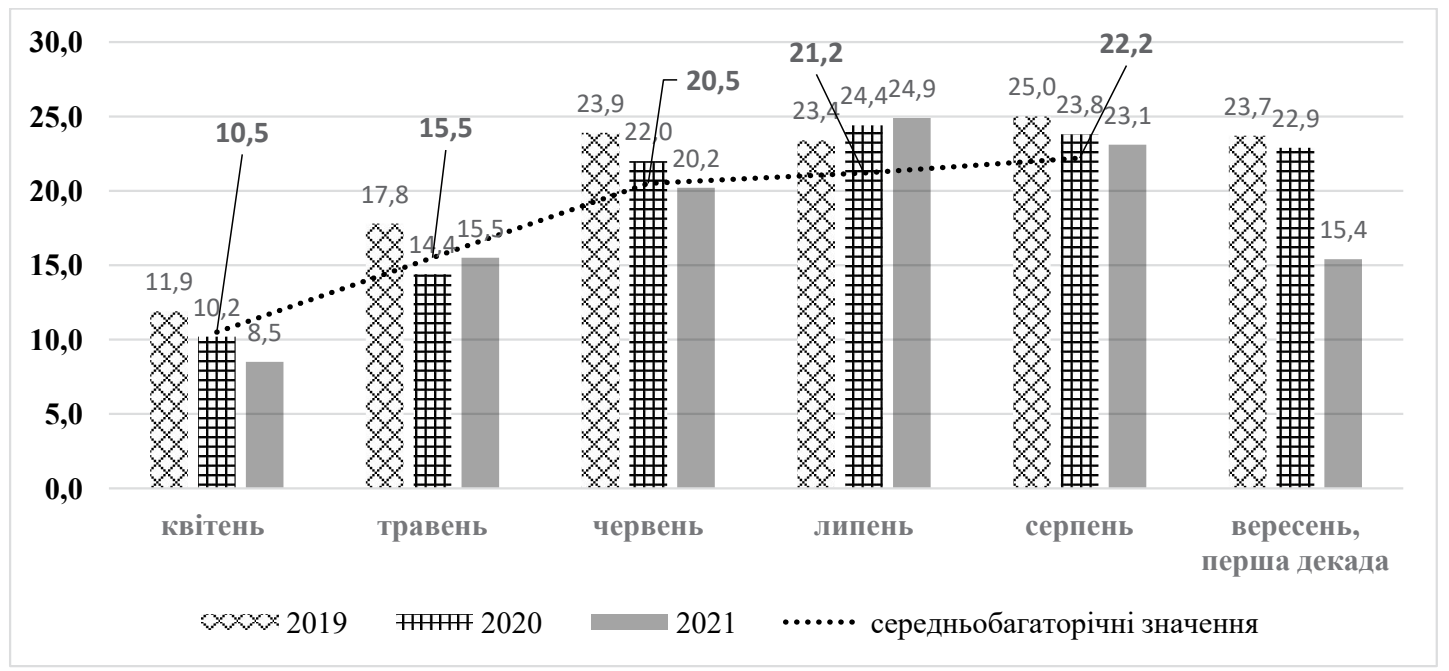

Рuc. 2. Середньомісячна температура повітря за вегетаційний період вирощування соняшнику за 2019-2021 рр., ${ }^{\circ} \mathrm{C}$

Аналізуючи погодні умови 2019-2021 років досліджень, встановлено, що за вегетаційний період вирощування соняшнику зафіксовано 235-364 мм опадів, що становить 106-120\% від середньобагаторічних показників, проте розподіл їх був нерівномірним. Найбільш сприятливим для вирощування соняшнику був 2021 р, за період вегетації випало 364 мм опадів, що становить $159 \%$ норми, щодо весняних запасів вологи в метровому шарі ґрунту в роки проведення досліджень, то вони різнилися майже вдвічі. Так, у 2019 році запаси вологи становили 69 мм, в 2020 році - 41 мм та 89 мм у 2021 році. Необхідно відзначити і той факт, що у 2021 році випадіння опадів відбувалося у критичні фази розвитку рослин, саме у період бутонізації - цвітіння. Відповідно, у генеративну фразу розвитку рослини соняшника не потерпали від нестачі вологи, в подальшому усі процеси від цвітіння і наливу насіння відбувалися без прояву стресових умов.

Результатами спостережень встановлено, що в 2019 та 2020 рр. друга половина вегетації агроценозу соняшника протікала за жорсткого дефіциту ґрунтового і повітряного зволоження. Розвиток рослин у цей період відбувався в умовах постійних стресів від нестачі зволоження та під впливом високих температур повітря (рис. 2).

Погодні умови 2020 року для розвитку соняшнику були складними впродовж усього періоду вегетації культури. Високий температурний режим на фоні недостат- 
нього зволоження призводив до скорочення міжфразних періодів розвитку рослин. Це явище не $є$ позитивним фактором, особливо на фоні вкрай низького забезпечення вологою (41 мм) метрового шару ґрунту перед сівбою в 2020 вегетаційному році. Високий температурний режим у подальшому та низька вологість повітря зумовили інтенсивну витрату ґрунтової вологи на транспірацію та випаровування.

Щодо температурних показників, то за 2019 та 2020 досліджувані роки середньомісячна температура повітря була вищою за відповідні середньобагаторічні дані. У 2021 році температурний режим вегетаційного періоду рослин соняшника був загалом нижчий порівняно із середньобагаторічними значеннями, виключенням був липень 2021 року. Добрі умови зволоження 2021 року на фоні задовільного температурного режиму (без екстремально високих показників) мали позитивний вплив на протікання міжфазних періодів рослин. Вегетаційний період соняшника мав тенденцію до пролонгації фотосинтетичної діяльності, що позитивно відобразилося на продуктивності агроценозу взагалі.

У посушливих умовах Південного Степу України рівень вологозабезпечення ґрунту $є$ одним із вирішальних фракторів формування продуктивності агроценозів. Усі агрозаходи, спрямовані на збереження вологи, $€$ головними в землеробстві степової зони [17, с. 30 ; 18 , с. 41,19 c. 42$]$

Рівень урожайності культури $є$ основним показниками ефективності вирощування культури, він може залежати і від генетичних особливостей гібридів, реакцій на ґрунтово-кліматичних умови вирощування й елементи сортової агротехніки [20, с. 29]. Результатами досліджень доведено, що внесення різних росторегулюючих препаратів $€$ ефективним та дієвим способом поліпшення умов розвитку рослин соняшника (табл. 1).
Дійсно, впродовж 2019-2021 років досліджень спостерігається стійке зростання урожаю від застосування росторегулюючих речовин. Гібриди соняшнику Оплот і П64ГЕ133 у середньому по досліду формували найбільшу продуктивність за роки проведення досліджень під впливом росторегулюючих речовин. Щодо гібридів ДСЛ 403 та 8Х477КЛ, то вони дещо поступалися за рівнем врожайності вищезгаданим гібридам, а Гектор взагалі поступався за продуктивністю усім досліджуваним гібридам. Найвищу продуктивність досліджувані гібриди формували у сприятливий 2021 рік, а в екстремальний за метеоумовами 2020 рік усі гібриди мали тенденцію до зниження врожайності майже на $30 \%$.

Аналіз наведених експериментальних даних у таблиці 1 дає можливість стверджувати, що позакореневі обробки комбінованими росторегулюючими препаратами мали позитивний вплив на підвищення продуктивності усіх досліджуваних гібридів соняшнику. Так, найвищу врожайність по досліду в середньому за роки проведення досліджень ссоормував гібрид соняшнику Оплот - 2,75 т/га у варіанті обробітку рослин Хелафрітом Комбі. Дещо поступався за врожайністю гібрид П64ГЕ133, формуючи за таких умов урожайність 2,67 т/га.

Умови півдня зони Степу України характеризується нестійким та нерівномірним зволоженням, відповідно $є$ зоною ризикованого землеробства. За таких умов основним завданням $€$ максимально ефективно використовувати запаси вологи в ґрунті на час сівби культури та опади впродовж вегетаційного періоду. Спостереження за динамікою вологи метрового шару ґрунту впродовж вегетації рослин показали, що гібриди по-різному її використовували. Зумовлено це генетичними особливостями того чи іншого гібриду, а також впливом позакореневих обробок рослин росторегулюючими препаратами (табл. 2).

Урожайність соняшника залежно від позакореневих обробок росторегулюючими препаратами

Таблиця 1 за роки проведення досліджень, т/га

\begin{tabular}{|c|c|c|c|c|c|}
\hline \multirow{2}{*}{ Гібриди (A) } & \multirow{2}{*}{$\begin{array}{l}\text { Препарат } \\
\text { (B) }\end{array}$} & \multicolumn{3}{|c|}{ Роки } & \multirow{2}{*}{$\begin{array}{l}\text { Середня } \\
\text { за } 3 \text { роки }\end{array}$} \\
\hline & & 2019 & 2020 & 2021 & \\
\hline \multirow{3}{*}{ Оплот } & Без препаратів (контроль) & 2,82 & 1,98 & 2,88 & 2,56 \\
\hline & Архітект & 3,07 & 2,01 & 3,12 & 2,73 \\
\hline & Хелафіт Комбі & 3,10 & 2,04 & 3,11 & 2,75 \\
\hline \multirow{3}{*}{ Гектор } & Без препаратів (контроль) & 1,92 & 1,54 & 2,04 & 1,83 \\
\hline & Архітект & 2,14 & 1,68 & 2,23 & 2,02 \\
\hline & Хелафіт Комбі & 2,10 & 1,72 & 2,22 & 2,01 \\
\hline \multirow{3}{*}{ ДСЛ 403} & Без препаратів (контроль) & 2,44 & 1,83 & 2,54 & 2,27 \\
\hline & Архітект & 2,55 & 1,88 & 2,86 & 2,43 \\
\hline & Хелафіт Комбі & 2,60 & 1,93 & 2,90 & 2,48 \\
\hline \multirow{3}{*}{ П64ГЕ133 } & Без препаратів (контроль) & 2,71 & 1,90 & 2,92 & 2,51 \\
\hline & Архітект & 2,88 & 1,95 & 3,05 & 2,63 \\
\hline & Хелафіт Комбі & 2,89 & 2,02 & 3,10 & 2,67 \\
\hline \multirow{3}{*}{ 8Х477КЛ } & Без препаратів (контроль) & 2,22 & 1,68 & 2,41 & 2,10 \\
\hline & Архітект & 2,37 & 1,71 & 2,96 & 2,35 \\
\hline & Хелафіт Комбі & 2,37 & 1,74 & 3,09 & 2,40 \\
\hline \multirow{3}{*}{ HIP05,т/га } & A & 0,09 & 0,07 & 0,09 & - \\
\hline & $\mathrm{B}$ & 0,12 & 0,11 & 0,10 & - \\
\hline & $A B$ & 0,25 & 0,21 & 0,24 & - \\
\hline
\end{tabular}


Водний баланс соняшнику залежно від позакореневих обробок росторегулюючими препаратами, середнє за 2019-2021 рр.

\begin{tabular}{|c|c|c|c|c|c|c|c|}
\hline \multirow{2}{*}{ Гібриди } & \multirow{2}{*}{ Препарат } & \multicolumn{2}{|c|}{$\begin{array}{c}\text { Запас вологи у шарі } \\
\text { 0-100 см, м³/га }\end{array}$} & \multirow{2}{*}{ 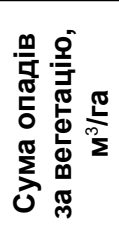 } & \multirow{2}{*}{ 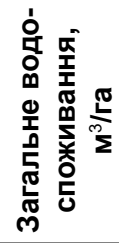 } & \multirow{2}{*}{ 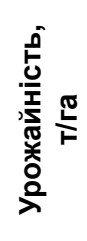 } & \multirow{2}{*}{ 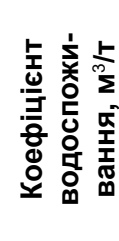 } \\
\hline & & $\begin{array}{c}\text { початок } \\
\text { сівби }\end{array}$ & $\begin{array}{c}\text { повна } \\
\text { стиглість }\end{array}$ & & & & \\
\hline \multirow{3}{*}{ Оплот } & Без препаратів (контроль) & 663 & 288 & 3030 & 3405 & 2,56 & 1330 \\
\hline & Архітект & 663 & 280 & 3030 & 3413 & 2,73 & 1250 \\
\hline & Хелафіт Комбі & 663 & 274 & 3030 & 3419 & 2,75 & 1243 \\
\hline \multirow{3}{*}{ Гектор } & Без препаратів (контроль) & 663 & 288 & 3030 & 3405 & 1,83 & 1860 \\
\hline & Архітект & 663 & 277 & 3030 & 3416 & 2,02 & 1691 \\
\hline & Хелафіт Комбі & 663 & 272 & 3030 & 3421 & 2,01 & 1702 \\
\hline \multirow{3}{*}{ дсл 403} & Без препаратів (контроль) & 663 & 288 & 3030 & 3405 & 2,27 & 1500 \\
\hline & Архітект & 663 & 274 & 3030 & 3419 & 2,43 & 1406 \\
\hline & Хелафіт Комбі & 663 & 275 & 3030 & 3418 & 2,48 & 1378 \\
\hline \multirow{3}{*}{ П64ГЕ133 } & Без препаратів (контроль) & 663 & 288 & 3030 & 3405 & 2,51 & 1357 \\
\hline & Архітект & 663 & 270 & 3030 & 3423 & 2,63 & 1301 \\
\hline & Хелафіт Комбі & 663 & 268 & 3030 & 3425 & 2,67 & 1283 \\
\hline \multirow{3}{*}{ 8Х477КЛ } & Без препаратів (контроль) & 663 & 288 & 3030 & 3405 & 2,10 & 1621 \\
\hline & Архітект & 663 & 273 & 3030 & 3420 & 2,35 & 1455 \\
\hline & Хелафіт Комбі & 663 & 283 & 3030 & 3410 & 2,40 & 1421 \\
\hline
\end{tabular}

Запаси продуктивної вологи під час початку сівби можна класифрікувати як задовільні. Наприкінці вегетації соняшника у фразу повної стиглості запаси вологи метрового шару набували мінімальних значень. Коефіцієнт водоспоживання $€$ інтегральним виразом усіх складників водного режиму. Аналізом результатів водного балансу встановлено, що за умов застосування комбінованих препаратів коефіцієнт водоспоживання усіх досліджуваних гібридів мав тенденцію до зниження порівняно з контрольними варіантами, де позакоренева обробка рослин соняшника не проводилася. Так, найнижчий рівень коефіцієнту водоспоживання $\left(1283 \mathrm{~m}^{3} / \mathrm{T}\right)$ було зафріксовано у гібриду П64ГЕ133 за умов обробки рослин соняшника комбінованим препаратом біологічного походження Хелафіт Комбі, а найвищим він був у гібриду Гектор (1860 м³/га) на контрольному варіанті. Таке зменшення коефіцієнту водоспоживання в усіх досліджуваних гібридів під впливом обробітку рослин соняшника багатофункціональними препаратами свідчить про більш економне використання ґрунтової вологи на утворення одиниці врожаю.

Висновки і пропозиції. Результатами польових досліджень доведено, що проведення позакореневих обробок рослин гібридів соняшника високоолеїнового типу багатофункціональними препаратами Архітект та Хелафіт Комбі мали позитивний вплив на продуктивність агроценозу усіх досліджуваних гібридів. Найвища урожайність 2,75 т/га за роки проведення досліджень по досліду сфрормована у гібриду Оплот у варіанті проведення позакореневих обробок рослин Хелафітом Комбі. Внесення росторегулюючих препаратів на початкових етапах росту і розвитку соняшнику приводить до покращення умов вегетації та підвищення стійкості рослин до прояву стресів від дії високих температур та нестачі вологи. Досліджуванні препарати сприяють більш економному використанню ґрунтової вологи на формування одиниці врожаю, про що свідчить зменшення коефіцієнту водоспоживання за всіма досліджуваними гібридами. Найнижчий коефіцієнт водоспоживання 1283 м³/т було встановлено у гібриду П64ГЕ133 за умов обробки рослин соняшника комбінованим препаратом біологічного походження Хелафіт Комбі. Позакореневі обробки рослин комбінованими росторегулюючими препаратами приводили до оптимізації водоспоживання агроценозу взагалі.

\section{СПИСОК ВИКОРИСТАНОÏ ЛІТЕРАТУРИ:}

1. Домарацький Є.О. Волога для соняшнику. The Ukrainian Farmer. №12 (132), 2020. С. 56-57.

2. Базалій В.В., Домарацький Є.О., Козлова О.П. Вплив біофунгіцидів і стимуляторів росту на продуктивність соняшнику та якість олійної сировини. Зрошуване землеробство. 2019. № 71. С. 5-10.

3. Козлова О.П. Продуктивність соняшнику при застосуванні біопрепаратів та стимуляторів росту у технології вирощування на Півдні України (Автореферат на здобуття наукового ступеня кандидата сільськогосподарських наук за спеціальністю 06.01. 09 - рослинництво). // Херсон, 2019. 20 с.

4. Бобир С.О. Зміна клімату планети та боротьба з нею. Безпека життя і діяльності людини: теорія та практика : збірник наук. праць Всеукр. наук.-практ. конф., присвяченої Всесвітнім Дням цивільної оборони та охорони праці, (Полтава, 23-24 квітня 2020 р.) / упоряд., і ред.: В.П. Титаренко, А.М. Хлопов. Полтава : ПНПУ імені В.Г. Короленка, 2020. С. 339-340.

5. П'ятакова В.Ф., Берлінський М.А. Вплив змін клімату на екосистему української частини чорноморського басейну як складова глобального потепління / 
Тези I Міжнародної Інтернет-конференції 25 лютого 2021 року «Екологічна безпека - сучасні напрямки та перспективи вищої освіти», 2021. Херків. С. 101-103.

6. Пічура В.І. Зональні закономірності вікових змін клімату на території басейну р. Дніпро. Вісник Дніпропетровського державного аграрно-економічного університету, 2017. №. 2. С. 62-73.

7. Вожегова Р.А. Перспективи використання зрошення для підвищення продуктивності сільськогосподарської галузі на глобальному та локальному рівнях в умовах змін клімату. Зрошуване землеробство, 2016. Вип. 65. С. 5-10.

8. Лавренко Н.М., Пугачова К.Є. Вплив змін клімату на сільське господарство в Україні / Матеріали III-ї Міжнародної науково-практичної конференції «Вплив кліматичних змін на просторовий розвиток територій Землі: наслідки та шляхи вирішення» (11-12 червня 2020 року), 2020. С. 141-144.

9. Домарацький Є.О., Кюрчев С.В., Мітрясова О.П., Пастушенко C.I. Потенційні небезпеки і сучасні рішення щодо адаптації балансу водних ресурсів півдня України до глобальних змін клімату / Збірник тез IV Міжнародної науково-практичної конференції «Кліматичні зміни та сільське господарство. Виклики для аграрної науки та освіти» Київ, НМЦ ВФПО, 2021 - C. 69-72.

10. Ходоніцька О.О., Кур'ята В.Г. Продуктивність льону-кучерявцю на дію сумішку регуляторів росту. Вчені записки Таврійського національного університету ім. В.І. Вернадського: Серія «Біологія, Хімія». 2013. T.26(65). №3. C. 203-210.

11. Шевченко А.О. Регулятори росту в рослинництві ефективний елемент сільськогосподарських технологій. Стан та перспективи. Регулятори росту у землеробстві. Зб. наук. праць. К. 1999. С. 8-14.

12. Громов А.А., Щукін В.Б., Воравна В.Н. Эффрективность регуляторов роста и биопрепаратов на озимой пшенице и проса. Земледелие. 2012. №6. С. 34-35.

13. Солодушко М.М. Ефективність рістрегулюючих речовин та мікродобрив при вирощуванні пшениці озимої в зоні Північного Степу. Бюллетень Інституту сільського господарства степової зони України НААН, 2016. №10. С. 73-78.

14. ДомарацькийЄ.О.,ДобровольськийА.В., БазалійВ.В., Пічура В.І., Домарацький О.О. Соняшник: екологічні шляхи оптимізації його живлення. Монографія / Херсон: Олді-Плюс, 2020 р. 160 с.

15. Цилюрик O.І., Кохан А.В., Судак В.М., Горбатенко A.I. Водний режим у посівах соняшнику залежно від обробітку ґрунту та рівня мінерального живлення. Вісник ЦНЗ АПВ Харківськоїобласті, 2017. Вип. 22. С. 62-73.

16. Голубенко І.А., Савельєва О.М., Попович О.Б. ОсобливостівирощуваннясоняшникувумовахПівдня України. Охорона грунтів. Київ, 2020. С. 186-191.

17. Базалій В.В., Бойчук І.В., Лавриненко Ю.О., Базалій Г.Г., Домарацький Є.О., Ларченко О.В. Особливості формування ознак продуктивності і урожайності у сортів пшениці озимої за різних умов вирощування. Фактори експериментальної еволюції організмів. 2020. Т. 27. С. 29-34.

18. Домарацький Є.О. Методи пом'якшення негативної дії водного стресу у рослин ріпаку озимого. Вісник аграрної науки Причорномор'я, 2018. Вип.2. С. 39-45.
19. Добровольський А.В., Домарацький Є.О. Особливості реалізації стимулюючої дії комплексних препаратів рослинами соняшника на початкових етапах органогенезу. Аграрний вісник Причорномор'я, 2017. Вип. 84-2. С. 39-45.

20. Гамаюнова В.В., Кудріна В.С. Водоспоживання соняшнику залежно від застосування біопрепаратів за вирощування в умовах Південного Степу України. "Наукові горизонти». SCIENTIFIC HORIZONS, 2018. № 7-8 (70). C. 28-35.

\section{REFERENCES:}

1. Domarats'kyy YE.O. Voloha dlya sonyashnyku. [Moisture for sunflower] The Ukrainian Farmer. №12 (132), 2020. S.56-57.[ in Ukraine]

2. Bazaliy V.V., Domarats'kyy YE.O., Kozlova O.P. Vplyv biofunhitsydiv i stymulyatoriv rostu na produktyvnist' sonyashnyku ta yakist' oliynoyi syrovyny.[ Influence of biofungicides and growth stimulants on sunflower productivity and quality of oil raw materials.] Zroshuvane zemlerobstvo. 2019. № 71. S. 5-10. [ in Ukraine]

3. Kozlova O.P. Produktyvnist' sonyashnyku pry zastosuvanni biopreparativ ta stymulyatoriv rostu u tekhnolohiyi vyroshchuvannya na Pivdni Ukrayiny [Productivity of sunflower in the use of biological products and growth stimulants in the technology of cultivation in the South of Ukraine](Avtoreferat na zdobuttya naukovoho stupenya kandydata sil's'kohospodars'kykh nauk za spetsial'nistyu 06.01. 09-roslynnytstvo). // Kherson, 2019. 20 s. [in Ukraine]

4. Bobyr S.O. Zmina klimatu planety ta borot'ba z neyu. Bezpeka zhyttya i diyal'nosti lyudyny: teoriya ta praktyka : zbirnyk nauk. prats' Vseukr. [Climate change and the fight against it. Safety of human life and activity: theory and practice: a collection of sciences. works All-Ukrainian] nauk.-prakt. konf., prysvyachenoyi Vsesvitnim Dnyam tsyvil'noyi oborony ta okhorony pratsi, (Poltava, 23-24 kvitnya 2020 r.) / uporyad., i red.: V. P. Tytarenko, A. M. Khlopov. - Poltava : PNPU imeni V.H. Korolenka, 2020. S. 339-340. [in Ukraine]

5. P"yatakova V.F., Berlins'kyy M.A. Vplyv zmin klimatu na ekosystemu ukrayins'koyi chastyny chornomors'koho baseynu yak skladova hlobal'noho poteplinnya [The impact of climate change on the ecosystem of the Ukrainian part of the Black Sea basin as part of global warming] / Tezy I Mizhnarodnoyi Internet-konferentsiyi 25 lyutoho 2021 roku «Ekolohichna bezpeka - suchasni napryamky ta perspektyvy vyshchoyi osvity», 2021. Kherkiv. S.101-103. [in Ukraine]

6. Pichura V.I. Zonal'ni zakonomirnosti vikovykh zmin klimatu na terytoriyi baseynu [Zonal patterns of age-related climate change in the Dnieper basin.] r. Dnipro. Visnyk Dnipropetrovs'koho derzhavnoho ahrarno-ekonomichnoho universytetu, 2017. №. 2. S. 62-73. [in Ukraine]

7. Vozhehova R.A. Perspektyvy vykorystannya zroshennya dlya pidvyshchennya produktyvnosti sil's'kohospodars'koyi haluzi na hlobal'nomu ta lokal'nomu rivnyakh $v$ umovakh zmin klimatu. [Prospects for the use of irrigation to increase the productivity of the agricultural sector at the global and local levels in the context of climate change] Zroshuvane zemlerobstvo, 2016. Vyp. 65. S. 5-10. [in Ukraine] 
8. Lavrenko N.M., Puhachova K.YE. Vplyv zmin klimatu na sil's'ke hospodarstvo $v$ Ukrayini [The impact of climate change on agriculture in Ukraine] / Materialy III-yi Mizhnarodnoyi naukovo-praktychnoyi konferentsiyi «Vplyv klimatychnykh zmin na prostorovyy rozvytok terytoriy Zemli: naslidky ta shlyakhy vyrishennya» (11-12 chervnya 2020 roku), 2020. S. 141-144. [in Ukraine]

9. Domarats'kyy YE.O., Kyurchev S.V., Mitryasova O.P., Pastushenko S.I. Potentsiyni nebezpeky i suchasni rishennya shchodo adaptatsiyi balansu vodnykh resursiv pivdnya Ukrayiny do hlobal'nykh zmin klimatu [Potential dangers and modern solutions for adapting the balance of water resources in southern Ukraine to global climate change] / Zbirnyk tez IV Mizhnarodnoyi naukovo-praktychnoyi konferentsiyi «Klimatychni zminy ta sil's'ke hospodarstvo. Vyklyky dlya ahrarnoyi nauky ta osvity» Kyyiv, NMTS VFPO, 2021 S. 69-72. [in Ukraine]

10. Khodonits'ka O.O., Kur"yata V.H. Produktyvnist' l'onu-kucheryavtsyu na diyu sumishku rehulyatoriv rostu. [Productivity of flax-curly on the action of a mixture of growth regulators.] Vcheni zapysky Tavriys'koho natsional'noho universytetu im. V.I. Vernads'koho: Seriya «Biolohiya, Khimiya». 2013. T. 26 (65). №3. S. 203-210. [in Ukraine]

11. Shevchenko A.O. Rehulyatory rostu v roslynnytstvi efektyvnyy element sil's'kohospodars'kykh tekhnolohiy. [Growth regulators in crop production are an effective element of agricultural technologies.] Stan ta perspektyvy. Rehulyatory rostu u zemlerobstvi. Zb. nauk. prats'. K. 1999. S. 8-14. [in Ukraine]

12. Gromov A.A., Shchukín V.B., Voravna V.N. Effektivnost' regulyatorov rosta i biopreparatov na ozimoy pshenitse i prosa. [The effectiveness of growth regulators and biological products on winter wheat and millet] Zemledeliye. 2012. №6. S. 34-35. [in Ukraine].

13. Solodushko M.M. Efektyvnist' ristrehulyuyuchykh rechovyn ta mikrodobryv pry vyroshchuvanni pshenytsi ozymoyi v zoni Pivnichnoho Stepu. [Efficiency of growth-regulating substances and microfertilizers in winter wheat cultivation in the Northern Steppe zone.] Byulleten' Instytutu sil's'koho hospodarstva stepovoyi zony Ukrayiny NAAN, 2016. №10. S. 73-78[in Ukraine]

14. Domarats'kyy YE.O., Dobrovol's'kyy A.V., Bazaliy V.V., Pichura V.I., Domarats'kyy O.O. Sonyashnyk: ekolohichni shlyakhy optymizatsiyi yoho zhyvlennya. Monohrafiya [Sunflower: ecological ways to optimize its nutrition.] / Kherson: Oldi-Plyus, 2020 r. 160 s. [in Ukraine]

15. Tsylyuryk O.I., Kokhan A.V., Sudak V.M., Horbatenko A.I. Vodnyy rezhym u posivakh sonyashnyku zalezhno vid obrobitku gruntu ta rivnya mineral'noho zhyvlennya. [Water regime in sunflower crops depending on tillage and level of mineral nutrition.] Visnyk TSNZ APV Kharkivs'koyi oblasti, 2017. Vyp. 22. S. 62-73. [in Ukraine]

16. Holubenko I.A., Savel'yeva O.M., Popovych O.B. Osoblyvosti vyroshchuvannya sonyashnyku v umovakh Pivdnya Ukrayiny. [Features of sunflower cultivation in the South of Ukraine.] Okhorona gruntiv. Kyyiv, 2020. S. 186-191.

17. Bazaliy V.V., Boychuk I.V., Lavrynenko YU.O., Bazaliy H.H., Domarats'kyy YE.O., Larchenko O.V. Osoblyvosti formuvannya oznak produktyvnosti i urozhaynosti u sortiv pshenytsi ozymoyi za riznykh umov vyroshchuvannya.
[Features of the formation of signs of productivity and yield in winter wheat varieties under different growing conditions.] Faktory eksperymental'noyi evolyutsiyi orhanizmiv. 2020. T.27. S. 29-34. [in Ukraine]

18. Domarats'kyy YE.O. Metody pom"yakshennya nehatyvnoyi diyi vodnoho stresu u roslyn ripaku ozymoho. [Methods of mitigating the negative effects of water stress in winter oilseed rape plants.] Visnyk ahrarnoyi nauky Prychornomor'ya, 2018. Vyp. 2. S. 39-45. [in Ukraine]

19. Dobrovol's'kyy A.V., Domarats'kyy YE.O. Osoblyvosti realizatsiyi stymulyuyuchoyi diyi kompleksnykh preparativ roslynamy sonyashnyka na pochatkovykh etapakh orhanohenezu. [Features of realization of stimulating action of complex preparations by sunflower plants at the initial stages of organogenesis.] Ahrarnyy visnyk Prychornomor'ya, 2017. Vyp. 84-2. S. 39-45. [in Ukraine]

20. Hamayunova V.V., Kudrina V.S. Vodospozhyvannya sonyashnyku zalezhno vid zastosuvannya biopreparativ za vyroshchuvannya v umovakh Pivdennoho Stepu Ukrayiny. [Water consumption of sunflower depending on the use of biological products for cultivation in the Southern Steppe of Ukraine.] "Naukovi horyzonty». SCIENTIFIC HORIZONS, 2018. № 7-8 (70). S. 28-35. [in Ukraine]

Домарацький Є.О., Добровольський А.В., Козлова О.П., Добровольський П.А., Лавришина О.Є. Шляхи оптимізації водоспоживання соняшника високоолеїнового типу за умов зміни клімату

Стаття присвячена висвітленню результатів польових досліджень, проведених впродовж 2019-2021 рр., із впливу багатофункціональних росторегулюючих препаратів із фунгіцидним ефектом Архітект тм та Хелафіт Комбі на формування продуктивності гібридів соняшнику високоолеїнового типу в посушливих умовах Південного Степу України, а також оптимізацію водоспоживання агроценозів соняшника за глобальних і регіональних змін клімату.

Дослідження проводили в незрошуваних умовах на дослідному полі ДУ «Миколаївської ДСДС І3З НААН» України на чорноземах південних малогумусних. Програмою наукових досліджень передбачалося закладення двофакторного польового досліду, в якому вивчалися гібриди соняшника - це Гектор і Оплот (оригінатор - Інститут рослинництва ім. В.Я. Юр'єва); ДСЛ403 та П64ГЕ133 (виробник Corteva, Brevant) та 8Х477КЛ (виробник Dow Seeds). У досліді застосовували багатофрункціональні росторегулюючі препарати хімічного походження Архітект ${ }^{\mathrm{TM}}$ та біологічного Хелафіт Комбі, вносили їх у вигляді позакореневих обробок гібридів соняшника у фазу 6-8 справжніх листків нормою 1 л/га. Щодо погодних умов 2019-2021 років досліджень, то їх можна класифікувати як середньопосушливі типові для цієї зони вирощування, проте найбільш сприятливим був 2021 рік. Щодо температурних показників, то за досліджувані роки середньомісячна температура повітря була вищою за відповідні середньобагаторічні дані.

Результати проведених дворічних польових досліджень показали, що проведення позакореневих обробок рослин гібридів соняшника високоолеїнового типу багатофункціональними препаратами Архітект та Хелафіт Комбі мали позитивний вплив на продуктивність агроце- 
нозу усіх досліджуваних гібридів. Найвища урожайність 2,75 т/га за роки проведення досліджень по досліду сформована у гібриду Оплот у варіанті проведення позакореневих обробіток рослин Хелафрітом Комбі. Внесення росторегулюючих препаратів на початкових етапах росту і розвитку соняшнику призводить до покращення умов вегетації та підвищенню стійкості рослин до прояву стресів від дії високих температур та нестачі вологи. Досліджуванні препарати сприяють більш економному використанню ґрунтової вологи на формування одиниці врожаю, про що свідчить зменшення коефіцієнту водоспоживання за всіма досліджуваними гібридами. Найнижчий коефіцієнт водоспоживання 1283 м $3 /$ т було встановлено у гібриду П64ГЕ133 за умов обробки рослин соняшника комбінованим препаратом біологічного походження Хелафіт Комбі. Позакореневі обробки рослин комбінованими росторегулюючими препаратами приводили до оптимізації водоспоживання агроценозу взагалі.

Ключові слова: соняшник високоолеїнового типу, багатофункціональні росторегулюючі препарати, Архітект, Хелафіт Комбі, гібрид, водоспоживання, урожайність.

Domaratsky E.O., Dobrovolsky A.V., Kozlova O.P., Dobrovolsky P.A., Lavrishina O.E. Ways of optimization of high oolein type sunflower consumption under climate change

The article is devoted to the results of field research conducted during 2019-2021 on the influence of multifunctional restrictive drugs with fungicidal effect ArchitektTM and Helafit Kombi on the formation of productivity of high-oleic sunflower hybrids in arid conditions of the Southern steppe of Ukraine and climate.

The research was carried out in non-irrigated conditions on the research field of the State Institution "Mykolayiv DSDS IZZ NAAS" of Ukraine on the chernozems of the southern low-humus. The research program provided for the establishment of a two-factor field experiment, which studied sunflower hybrids - Hector and Stronghold (originator - Yuryev Institute of Plant Breeding); DSL403 and P64GE133 (manufacturer Corteva, Brevant) and 8 X477KL (manufacturer Dow Seeds). The experiment used multifunctional restregulating drugs of chemical origin ArchitectTM and biological Helafit Combi, introduced them in the form of foliar treatments of sunflower hybrids in the phase of $6-8$ true leaves at a rate of 1 I / ha. Regarding the weather conditions of 2019-2021 years of research, they can be classified as moderately arid typical for this area of cultivation, but the most favorable year was 2021. In terms of temperature indicators, the average monthly air temperature over the years under study was higher than the corresponding long-term average data.

The results of two-year field studies showed that foliar treatment of plants of high-oleic sunflower hybrids with multifunctional drugs Architect and Helafit Kombi had a positive effect on the productivity of agrocenosis of all studied hybrids. The highest yield of $2.75 \mathrm{t} / \mathrm{ha}$ for the years of research is formed in the hybrid Oplot in the variant of foliar treatment of plants with Helafit Kombi

The introduction of growth-regulating drugs in the initial stages of growth and development of sunflower leads to improved growing conditions and increased resistance of plants to stress from high temperatures and lack of moisture. Research drugs contribute to the more economical use of soil moisture to form a unit of yield, as evidenced by the reduction of water consumption for all studied hybrids.

The lowest water consumption coefficient of $1283 \mathrm{~m}^{3} /$ $t$ was found in the hybrid P64GE133 under the conditions of treatment of sunflower plants with a combined preparation of biological origin Helafit Combi. Foliar treatment of plants with combined growth-regulating drugs led to the optimization of agrocenosis water consumption in general.

Key words: high-oleic sunflower, multifunctional growth-regulating drugs, Architect, Helafit Combi, hybrid, water consumption, yield. 